Praca poglądowa/Review paper

\title{
Rozwiązania w zakresie zarządzania ruchomością narządową i unieruchomień stosowanych w radioterapii podczas konferencji ESTRO 36 w Wiedniu.
}

\section{Comprehensive motion management and immobilisation solutions in radiation therapy.}

Krzysztof Kaczmarek ${ }^{1}$

${ }^{1}$ Zakład Radioterapii I, Wielkopolskie Centrum Onkologii, Poznań, Polska

\section{Streszczenie}

Celem niniejszej pracy było zwrócenie uwagi na najnowsze doniesienia technologiczne i trendy w teleradioterapii. Analizę oparto o wybrane raporty oraz problemy badawcze zaprezentowane podczas dorocznego spotkania ESTRO $36 \mathrm{w}$ Wiedniu.

\begin{abstract}
The aim of this work was to highlight attention to the latest technological reports and trends in teleradiotherapy. The analysis was based on selected reports and research problems presented during the annual ESTRO 36 meeting in Vienna.
\end{abstract}

Stowa kluczowe: estro36, ruchomość oddechowa, elektroradiolodzy.

Key words: estro 36, motion menegment, RTT, DIBH , ABC.

\section{Wprowadzenie}

Rozwiązania w zakresie zarządzania ruchomością narządową i unieruchomień stosowanych w radioterapii (Comprehensive motion management and immobilisation solutions in radiation therapy) to temat przewodni sesji elektroradiologicznej RTT (ang. radiation therapist) konferencji organizowanej w Wiedniu w dniach 05o9 maj 2017 przez European Society for Radiotherapy and Oncology - ESTRO.

Adres do korespondencji

Krzysztof Kaczmarek

Zakład Radioterapii I,

Wielkopolskie Centrum Onkologii, ul. Garbary 15, 61-866 Poznań, Polska

Telefon. +48618850757

e-mail: krzysztof.kaczmarek@wco.pl 
Niewątpliwie nowoczesne technologie zrewolucjonizowały radioterapię RT (ang. radiation therapy) oraz opiekę nad pacjentem onkologicznym na świecie. Niemniej jednak nadal poszukiwane są coraz lepsze rozwiązania w dziedzinie radioterapii oraz fizyki medycznej. Z tego też powodu na konferencji ESTRO można było zapoznać się z badaniami, doniesieniami naukowymi i innowacjami, które na przestrzeni kilku lat przyczynią się do znacznej poprawy leczenia pacjentów onkologicznych i podniesienia standardów radioterapii.

\section{Najistotniejsze wyniki}

Podczas konferencji ESTRO na w/w sesji dla elektroradiologów zwrócono między innymi uwagę na potrzeby i komfort pacjenta, zarówno ten fizyczny jak i psychiczny, w kontekście doboru unieruchomień oraz odtwarzalności ułożenia i precyzji w RT. Na przestrzeniu wielu lat stosowane w radioterapii unieruchomienia i techniki napromieniania ewoluowały podnosząc komfort pacjenta poprzezzastosowanielepszych materiałów i poprawę szybkości dostarczania dawki promieniowania( VMAT vs IMRT), jak również wzrostu precyzji jej dostarczania( MV portal vision vs IGRT MVCT). Ciągle jednak komfort pacjenta to jedna z głównych potrzeb człowieczeństwa[1]. Obecnie w radioterapii jest on oceniany zwykle w kontekście komfortu fizycznego, przy użyciu różnych metod, w tym skali VAS lub kwestionariuszy jakości życia.

Należy rozważać komfort fizyczny, percepcję mentalną i bierność pacjenta przy doborze unieruchomień w codziennej praktyce radioterapeutycznej. Niemniej jednak najistotniejszy wpływ na poczucie komfortu dla pacjenta onkologicznego ma rozmowa z personelem medycznym[2].

W drugiej części sesji zwrócono uwagę na zastosowanie mechanicznej wentylacji w radioterapii nowotworów charakteryzujących się dużą ruchomością narządową.

Ruchomość oddechowa u chorych na nowotwory złośliwe podczas radioterapii wymaga odpowiedniego przygotowania, w tym rozszerzenia planowanego pola leczenia, bramkowania oddechowego i interwencji w zakresie nauki prawidłowego oddychania. W tym celu przedstawiono badanie[3] obejmujące grupę $n=15$ osób przeszkolonych w zakresie oddychania przy użyciu wentylacji mechanicznej. Oceniano amplitudę oddechu za pomocą systemu Osiris.

W trakcie badania uzyskano zmniejszenie szybkości oddechu o 85\% oraz zmniejszenie objętości wdechu o 29\% w porównaniu do oddechu niewentylowanego;

Amplituda oddechu wynosiła $5 \pm 1 \mathrm{~mm}$ przy SD $\leq$ o,2mm, średnie HR $131 \pm 5 \mathrm{mmHg}$ przy tętnie $75 \pm 2$ bmp.Po zakończeniu badania średnie HR pozostało bez zmian, natomiast tętno wzrosło nieznacznie o +2 bmp. Żaden z pacjentów biorących udział w w/w badaniu nie zgłosił dyskomfortu!

Ta prosta technika stabilizowania ruchomości oddechowej może mieć ważne zastosowania w radioterapii.

Kolejną ciekawą publikacją było badanie obejmujące grupę $n=15$ pacjentów w wieku 37-74 lat poddawanych radioterapii na raka piersi przy wykorzystaniu metodą wstrzymanego wdechu DIBH (ang. Deep Inspiratory Breath Hold) z preoksygenacją i mechanicznie indukowaną hipokapnią w warunkach symulowanego leczenia radioterapią[4]. Osiągnięto następujące wyniki:

- Średni czas wstrzymanego oddechu wynosił 5,3 \pm 0,2 min. (10x dłużej niż obecnie się stosuje)

- średnie ciśnienie dwutlenku węgla $36 \pm 1(\mathrm{mmHg})$ i średnia saturacja $100 \%$; brak zaburzeń oddychania, zawrotów głowy, dreszczy, brak oznak stresu

- wzrost HR $125 \pm 3$ do $166 \pm 4 \mathrm{mmHg}$, normalizował się po 20s.;

- ruchomość znacznika na piersi <2mm w kierunku przednio-tylnym.

W wyżej wymienionym badaniu wynika, iż pacjenci z rakiem piersi mogą być odpowiednio przeszkoleni w zakresie leczenia metodą DIBH w warunkach symulowanego leczenia radioterapią. Możliwość zastosowania tej techniki w radioterapii jest obiecująca, jednakże po dalszych badaniach klinicznych z uwagi 
na wprowadzanie pacjenta w stan hipokapnii w wyniku zastosowania wentylacji mechanicznej.

Na konferencji zaprezentowano również sposób na zmniejszenie marginesów u pacjentów leczonych na raka wątroby za pomocą metod bramkowania oddechu. W publikacji Chang et al.[5] badaniu poddano 65 pacjentów napromienianych na wstrzymanym wydechu. Uzyskano zmniejszenie ruchomości wątroby $13 \mathrm{~mm}$ do 1,9mm co pozwoliło na redukcję marginesów PTV( ang. Planning Target Volume).

W podobnej publikacji Eccles et al.[6] potwierdził, że pozycja wątroby jest stabilna w tracie wstrzymanego wydechu a średnie przesunięcia wynosiły od 1,4mm do max $3,4 \mathrm{~mm}$.

Przedstawiono również roczne doświadczenie w napromienianiu przerzutów do wątroby w Haaglanden Madical Center w Holandii. Napromienili oni 42 pacjentów przy pomocy bramkowania oddechowego wykorzystując do tego od 1-6 frakcji terapeutycznych w średnio 2 łukach ARC VMAT. Przed rozpoczęciem leczenia uczono pacjentów techniki oddychania zwracając uwagę na ich możliwości fizyczne - wstrzymany wdech na 75\% wdechu maksymalnego przez ok. 30sek. Wykonywano następnie CT ( ang. Computed Tomography) wielokrotne celem planowania leczenia i określenia poziomów wychyleń przepony. Ustalono maksymalne marginesy PTV na poziomie $13 \mathrm{~mm}$. Pozycjonowanie pacjenta za pomocą weryfikacji obrazowej CBCT było wieloetapowe. Przed radioterapią, po korekcji ułożenia oraz po leczeniu. Ogólny czas napromieniania wynosił od 20 do 3ominut przy średniej ilości 20 wstrzymanych wdechów.

\section{Podsumowanie}

Podczas ESTRO 36 w panelu RTT dużo uwagi poświęcono komfortowi leczenia pacjenta i skróceniu czasu napromieniania jak również ograniczenia dawek w narządach zdrowych za pomocą zmniejszenia marginesów PTV przy użyciu nowatorskich metod napromieniania. Zwracano uwagę na korzyści jakie niesie ze sobą dane narzędzie radioterapeutyczne oraz konieczność posługiwania się nim w świadomy sposób , aby jego zalety wykorzystać dla dobra pacjenta.

\section{Konflikt interesu / Conflict of interest}

Nie występuje. / None.

\section{Finansowanie / Financial support}

Artykuł został sfinansowany z grantu Wielkopolskiego Centrum Onkologii w Poznaniu, nr 10/2017(154);

\section{Etyka/Ethics}

Treści przedstawione w artykule są zgodne z zasadami Deklaracji Helsińskiej, dyrektywami EU oraz ujednoliconymi wymaganiami dla czasopism biomedycznych.

\section{Piśmiennictwo / References}

[1] C. Pineau at al.,The systemic lupus erythematosus tri-nation study: longitudinal changes in physical and mental well-being, Rheumatology, Volume 44, Issue 6, June 2005, Pages 751-755

[2] Simon D. Goldsworthy, Kelly Tuke and Jos M. Latour. A focus group consultation round exploring patient experiences of comfort during radiotherapy for head and neck cancer. Journal of Radiotherapy in Practice, vol.15, issue 2,p.143-149, June 2016

[3] Michael J Parkes, Reducing the within-patient variability of breathing for radiotherapy delivery in conscious, unsedated cancer patients using a mechanical ventilator. Br J Radiol, v.89(1062); June 2016 $\mathrm{PMC}_{5258146}$ 
[4] Michael J Parkes, Safely prolonging single breath-holds to $>5 \mathrm{~min}$ in patients with cancer; feasibility and applications for radiotherapy. Br J Radiol,vol.89(1063); July 2016, PMC5257330

[5] Chang et al., Stereotactic body radiotherapy for colorectal liver metastases: a pooled analysis. Cancer 117:4060-4069

[6] Eccles et al., Reproducibility of liver position using active breathing coordinator for liver cancer radiotherapy. Int J Radioat Oncol Biol Phys 2006;63(3):751-159. 